\title{
Právo sell-out z pohledu teorie a praxe
}

\section{The Sell-out Right in Theory and Practice}

\author{
Michala Špačková*
}

\begin{abstract}
Abstrakt
Právo odkupu (sell-out) patř ke duiležitým, byt’ v praxi ne prǔliš často využivaným, nástrojuim ocbrany mensinových akcionáru. Právni úprava sell-out tuto skutečnost odráǧi pouze částečnè, kedy právo sell-out výslovnè zakotvuje prostrédnictvím generálni klauzule, coそ̌ lze vnimat jako jev pozitivni, nicménè dílǔ́ pravidla realizace práva odkupu plnè nereflektuji specifickou povabu qkoumanébo institutu. Cílem tohoto př̌spèvku neni pouze vytknout nejvètš̀ nedostatky právni úpravy sell-out, ale rovněž nastínit v úvahu prícházejicí varianty rěsení, zabrnujici mimo jïné i možnost aplikace funkèně srovnatelnébo práva na odkup.
\end{abstract}

\section{Klíčová slova}

Sell-out; squeeze-out; právo exitu; ochrana menšinových akcionárú.

\begin{abstract}
The sell-out right represents an important instrument of the protection of minority shareholders, despite its limited application in practice. The Czech regulation of the sell-out right reflects its meaning only partially. The explicit formulation of the sell-out rule (general clause) can be judged positively. On the other hand, the particular rules of the sell-out procedure don't fully respect the specific characteristics of the sell-out right. The aim of this article isn't only to point on the legislative shortcomings, but also to offer some applicable solutions, including the use of the functionally comparable exit right.
\end{abstract}

\section{Key words}

Sell-out Right; Squeeze-out Right; Exit Right; Protection of Minority Shareholders.

\section{Úvod}

Východiskem rozboru právní úpravy práva sell-out v tuzemském právním ráau je hlubší pochopení významu zkoumaného práva, a to v jeho jednotlivých podobách a variantách. Právo sell-out (sell-out right, buy out, Andienungsrecht) ${ }^{1}$ je zvláštním právem menšinových akcionářů požadujících odkup jimi držených účastnických cenných papírů. Uvedenému právu odpovídá povinnost hlavního akcionáře tyto účastnické cenné papíry odkoupit.

\footnotetext{
* Mgr. Michala Špačková, doktorandka, Katedra obchodního práva, Právnická fakulta Masarykovy univerzity, Brno / Ph.D. student, Department of Commercial Law, Faculty of Law, Masaryk University, Brno, Czech Republic / E-mail: msorokova@seznam.cz

1 Český jazykový ekvivalent „právo odkupu“ (『 395 zákona č. 90/2012 Sb., o obchodních společnostech a družstvech - ZOK) je terminologicky snadno zaměnitelný s jinými nástroji sloužícími $\mathrm{k}$ ochraně menšinových akcionářù, konkrétně s právem na odkup (\$89 ZOK), resp. s povinným odkupem (\$145 a $\ 308$ zákona č. 125/2008 Sb., o přeměnách obchodních společností a družstev ve znění pozdějších předpisů - PřemZ).
} 
Stejně jako squeeze-out je i sell-out právem podmíněným. V závislosti na formulaci podmínky lze rozlišit obecné právo sell-out ${ }^{2}$ spojené s předpokladem určitého (maximálního) podílu na základním kapitálu, resp. na hlasovacích právech, a dále zvláštní „sankční“ typ práva sell-out spojující právo odkupu s existencí určitého materiální důvodu spočívajícího ve zhoršení právního postavení drobných akcionářu či poškozování jejich zájmů v důsledku uplatňování vlivu majoritního akcionáře ve společnosti.

Právo sell-out je charakterizováno primárně jako zvláštní právo akciové minority směřující k její ochraně. Jeho význam je jak samostatný, tak doplňkový, kdy některé pozitivní efekty zkoumaného práva vyniknou až v kombinaci s jinými právními instituty. V literatuře bývá právo sell-out pravidelně označováno jako určitý protipól práva squeeze-out. ${ }^{3}$ Je však nutné zdůraznit, že právo sell-out má své vlastní ratio.

Vlastní samostatné opodstatnění existence práva sell-out lze spojit především se situací tzv. uzamčení ve společnosti (lock-in). Obecné právo sell-out mưže v uvedeném kontextu fungovat jako užitečný nástroj ochrany minorit, i ve chvíli, kdy drobným akcionárum nehrozí bezprostřední riziko zneužití vlivu ze strany hlavního akcionáře. ${ }^{4} \mathrm{~V}$ situaci nedostatečně likvidního trhu a omezené faktické možnosti využití smluvních mechanismư ${ }^{5}$ představuje povinný odkup účastnických cenných papírů nezrrídka jediný dostupný nástroj ukončení účasti menšinových společníků ve společnosti (lock-in remedy). Význam práva sell-out se dále projevuje při nastoupení zvláštních okolností, at' již jde o situace charakterizované útlakem menšinových akcionářo (minority oppression), v jehož důsledku může docházet $\mathrm{k}$ podstatnému zhoršení jejich postavení, takže další setrvání ve společnosti pro ně ztrácí význam (sell-out jako prostředek proti útisku - oppression remedy)

2 Obecný typ sell-out, lze dále rozlišovat podle toho, zda je připuštěn pouze $\mathrm{v}$ tzv. kótovaných společnostech, či ve všech typech akciových společností bez rozdílu. Právo sell-out lze diferencovat i podle jiných kritérií, např̀. podle vztahu k předchozí nabídce převzetí lze rozlišit (stejně jako u práva squeeze-out) obecný (korporátnî) sell-out a následný sell-out.

3 ŠTENGLOVÁ, Ivana, HAVEL, Bohumil, CILEČEK, Filip, KUHN, Petr, ŠUK, Petr. Zákon o obchodních korporacích. 1. vyd. Praha: Nakladatelství C. H. Beck, 2013, s. 600. ISBN 978-80-7400-480-3.

4 The European Model Company Act (EMCA) Draft 2015 [online], 2015, s. 279 [cit. 11. 11. 2016]. Dostupné z: http://law.au.dk/fileadmin/Jura/dokumenter/forskning/projekter/EMCA/EMCA_Introduktion.pdf

5 Smluvnímu řešení problému uzamčení sice teoreticky nic nebrání, avšak v praxi se s ním lze setkat spíše ojediněle. V zahraničí, zejména v USA, jsou nicméně klauzule umožňující odkoupení podílů (buy out provisions, tag-along, buy/sell agreement) poměrně oblíbené, zejména u společníků uzavřených společností rodinného typu. Uvedené klauzule obsažené např. $\mathrm{v}$ separátních akcionářských dohodách, př́ípadně ve zrrizovatelských dokumentech společnosti, tak nabízí určitou smluvní alternativu k právu sell-out zakotveném v právním předpise. Faktickou podmínkou jejich sjednání je nicméně dostatečná vyjednávací schopnost obou smluvních partnerů. 
či při vzniku patové situace blokující rozhodování o zásadních záležitostech společnosti (sell-out jako prostředek řešení patové situace - deadlock remedy). ${ }^{6}$

V oblasti doplňkového působení práva sell-out lze identifikovat zvláštní význam zkoumaného oprávnění v kombinaci s dalšími právními instituty, konkrétně právem squeeze-out a nabídkami převzetí. Pokud jde o prvně jmenovaný institut, je nutné zdůraznit především určitou legitimizační funkci práva sell-out ve vztahu k právní úpravě squeeze-out. ${ }^{7}$ Sell-out funguje jako určitá protiváha práva vytěsnění, kdy zvláštní oprávnění svěřené hlavnímu akcionáři je kompenzováno prostřednictvím obligatorního odkupu ve prospěch menšinových akcionářù. V kombinaci s nabídkami převzetí je pak nutné zmínit pozitivní vliv práva sell-out při řešení problému akceptace nekvalitních nabídek převzetí z důvodu obavy z uzamčení akcionářů v cílové společnosti (pressure-to tender problem).

\section{Sell-out a squeeze-out}

Právo sell-out je často definováno opozitně k právu squeeze-out, kdy za nejstručnější definici lze považovat označení práva sell-out jako protipólu squeeze-out (reverse squeeze-out $)^{8}$. Uvedený príměr je nicméně poněkud zjednodušující, nebot' právo sell-out je samostatným právním institutem, který má vlastní právně-ekonomické ratio a jako nástroj ochrany akciové minority má význam i tehdy, pokud by squeeze-out v právním řádu regulován nebyl. Právní rády zakotvující právní úpravu squeeze-out sice zpravidla paralelně upravují i právo sell-out, jež lze uplatnit za zásadně stejných podmínek, avšak lze narazit i na právní řády upravující instituty nezávisle na sobě. Vysledovat lze dále jak simultánní, tak postupné zavádění obou práv do právní úpravy. Ne vždy byl přitom squeeze-out zakotven jako první v pořadí. ${ }^{9}$

Zkoumané instituty se neliší pouze důvody hovořícími ve prospěch jejich regulace, či zájmy, kterým mají sloužit, ale i praktickým použitím. Zatímco squeeze-out nachází praktické uplatnění v zásadě bez ohledu na veřejnou obchodovatelnost akcií emitova-

6 Srov. napr. O`NEAL, Hodge, F. Arrangements Which Protect Minority Shareholders Against „,Squeeze-Outs“. Minnesota Law Review, 1961, Vol. 45, s. 537-558; či z novější literatury např̀. VENTORUZZO, Marco. Freeze-Outs: Transcontinental Analysis and Reform Proposals. Virginia Journal of International Law, 2010, Vol. 50, No. 4, s. 841-917.

7 Srov. bod 62. nálezu Pl. ÚS 56/05 ze dne 27. března 2008.

8 FERON, Benoit, DE LEENER, Marie-Laure. Belgium. In: CALKOEN, Willem, J. L. et al. Securities World: Jurisdictional Comparisons, European Lanyer reference. 3. rd., London: Sweet \& Maxwell, 2011, s. 52. ISBN 978-1-908239-01-3.

9 Jako př́klad lze uvést francouzskou právní úpravu, která zavedla právo sell-out již v roce 1989, zatímco právo squeeze-out bylo zakotveno až v roce 1993. Blíže k historii francouzské právní úpravy viz VAN DER ELST, Christoph, VAN DEN STEEN, Lientje. Balancing the Interests of Minority and Majority Shareholders: A comparative Analysis of Squeeze-out and Sell-out Rights. European Company and Financial Law Review [online]. 2009, s. 5 [cit. 11. 11. 2016]. DOI: 10.1515/ECFR.2009.391. Dostupné z: https:// www.researchgate.net/publication/247837852_Balancing_the_Interests_of_Minority_and_Majority_ Shareholders_A_Comparative_Analysis_of_Squeeze-out_and_Sell-out_Rights 
ných cílovou společností, využití sell-out (obecného i zvláštního typu) lze očekávat spíše $\mathrm{v}$ uzavřených společnostech (closed corporations), ve kterých je možnost odprodeje podílů prostřednictvím trhu omezená. Pravdou však je, že ve skutečnosti je obecný sell-out v praxi využíván zrrídka. ${ }^{10}$ Důvod je poměrně logický a souvisí s oblíbeností používání práva squeeze-out, které zpravidla bude využito jako první v pořadí. Spíše omezené praktické využití zejména obecného práva sell-out však nelze automaticky spojovat se závěry o malém významu institutu, nebot' sell-out má význam především preventivní a slouží tak jako určitá „pojistka“ před zneužitím vlivu hlavního akcionáře, resp. jako nástroj vyvážení postavení obou typů akcionářu s odlišnou rozhodovací silou. I v případě zvláštních druhů sell-out lze uvažovat o preventivním působení proti různým formám oportunistického chování ze strany hlavního akcionáře.

Přesto, anebo právě proto, že mezi oběma zkoumanými právy existuje řada rozdílů, lze v prŕpadě kombinace obou práv hovořit o určité amplifikaci jejich funkcí. Výsledné působení práva sell-out a práva squeeze-out tak vede ke snižování konfliktů a napětí ve vztazích mezi majoritními akcionáři prosazujícími zvýšení efektivity řízení společnosti a menšinovými akcionáři bojujícími o ochranu svého postaveni. ${ }^{11}$ Vzájemná kompenzace slabin obou institutů v duchu rčení quid pro quo je významným pozitivem komplementárního působení obou práv. ${ }^{12}$

Právo sell-out je pravidelně zmiňováno v pozitivním kontextu jako institut vyvažující zásah do vlastnického práva způsobený realizací práva squeeze-out v rámci debat o ústavní konformitě. ${ }^{13}$ Nutnost zajistit adekvátní ochranu práv menšinových akcionářu tak v podstatě zákonodárce $\mathrm{v}$ těch státech, které upravují právo squeeze-out, nepřímo donutila právo sell-out zakotvit. ${ }^{14}$ Právo sell-out zároveň funguje jako významný preventivní nástroj proti zneužití práva. Lze se domnívat, že hlavní akcionář bude již pouhým

10 VAN DER ELST, Christoph, VAN DEN STEEN, Lientje. Opportunities in the M \& A aftermarket: squeezing out and selling out. Universiteit Gent Financial Law Institute Working Paper [online]. 2006, No. 12, s. 5 [cit. 11. 11. 2016]. Dostupné z: https://papers.ssrn.com/sol3/papers.cfm?abstract_id=933609

11 Tamtéž, s. 12.

12 BURKART, Mike, PANUNZI, Fausto. Mandatory Bids, Squeeze-out, Sell-out and the Dynamics of the Tender Offer Process. ECGI - Law Working Paper [online]. 2003, No. 10, s. 20 [cit. 10. 11. 2016]. Dostupné z: https://papers.ssrn.com/sol3/papers.cfm?abstract_id $=420940$

13 Ačkoliv se hovoří o právu squeeze-out a sell-out jako o zrcadlových institutech, je pozoruhodné, že zatímco vytěsnění je tradičně spojeno s debatami na téma jeho ústavní konformity, v př́padě práva sell-out se s obdobnou diskuzí týkající se př́ípustnosti omezení vlastnického práva setkat nelze. Obdobná debata by přitom právě s ohledem na vzájemný vztah obou institutů měla probíhat i zde, nebot' i z pohledu majoritního akcionáře může znamenat povinnost odkupu omezení jeho vlastnického práva. Z určitého úhlu pohledu je hlavní akcionář de facto nucen nedobrovolně vynaložit peněžní prostředky $\mathrm{k}$ nákupu účastnických cenných papírů společnosti a měnit strukturu jím vlastněného majetku proti své vůli. Nabízí se tak otázka, zda tento zásah do vlastnického práva hlavního akcionáře obstojí z pohledu testu proporcionality, kterým byl v minulosti poměřován i squeeze-out.

14 VAN DER ELST, Christoph, VAN DEN STEEN, Lientje. Opportunities in the M \& A aftermarket: squeezing out and selling out. Universiteit Gent Financial Law Institute Working Paper [online]. 2006, No. 12, s. 15 [cit. 11. 11. 2016]. Dostupné z: https://papers.ssrn.com/sol3/papers.cfm?abstract_id=933609 
zakotvením uvedeného institutu odrazen od případného škodlivého jednání vưči menšinovým akcionářưm, jelikož v opačném případě by mu mohla vzniknout povinnost jejich podíly odkoupit. Na tuto pozitivní funkci je upozorňováno i v tzv. Winterově zprávě, která jako jeden ze dvou hlavních důvodů hovořících ve prospěch regulace práva sell-out poukazuje na skutečnost, že $\mathrm{v}$ návaznosti na zvýšení majoritního podílu $\mathrm{v}$ důsledku úspěšné nabídky převzetí hrozí drobným akcionářưm větší riziko zneužití dominantního postavení ze strany většinového akcionáře (např. formou expropriace či privatizace zisků společnosti). ${ }^{15}$ Uvedené riziko narůstá zejména v situacích, kdy velikost podílu majoritního akcionáře dosáhne takové výše, že minoritní akcionáři již nedosahují potřebné kvalifikované účasti ${ }^{16}$ pro výkon některých práv na ochranu akciové menšiny. ${ }^{17}$

Pozitivní působení lze však zaznamenat i v opačném směru, kdy právo squeeze-out kompenzuje př́padná negativa spojená s nijak neomezeným právem sell-out. Konkrétně totiž pomáhá eliminovat obstrukční potenciál aktivistické akciové minority. V prrípadě absence jiných motivů pro vytěsnění se teoreticky mohou potíže způsobené některými aktivistickými menšinovými akcionáři stát důvodem pro iniciaci práva squeeze-out. ${ }^{18}$ Z čistě racionálního hlediska lze předpokládat, že zástupci akciové minority se za okolností hrozícího vytěsnění šikanózního jednání pravděpodobně dopouštět nebudou, a ukáže-li se opak, majoritní akcionář bude mít k dispozici efektivní nástroj.

\section{Sell-out a nabídka převzetí}

V některých právních řádech se lze setkat s právem sell-out pouze $\mathrm{v}$ kombinaci s následným squeeze-out (take over squeeze-out), zatímco pro korporátní squeeze-out (corporate squeeze-out) právní úprava zrcadlový institut ve formě korporátního práva sell-out nefor-

15 WINTER, Jaap et al. Report of the High Level Group of Company Law Experts on Issues Related to Takeover Bids [online]. Brusel: Evropská komise, 2002, s. 62 [cit. 10. 11. 2016]. Dostupné z: http://ec.europa.eu/ internal_market/company/docs/takeoverbids/2002-01-hlg-report_en.pdf

16 V některých právních řádech je výše prahové hodnoty pro vytěsnění zákonodárcem nastavena tak, že dosažením rozhodného podílu pro squeeze-out je zároveň redukován podíl akciové minority potřebný pro realizaci zvláštních práv kvalifikovaných akcionářu. Srov. např. německou úpravu práv kvalifikovaných akcionářù v \122 odst. 2 či \254 odst. 2 Aktiengesetz a pravidlo zakotvující výši prahové hodnoty v \327a Aktiengesetz nebo švédskou úpravu zvláštních práv akciové minority nacházející se v kapitole 18 oddílu 11, resp. kapitole 25, oddílu 21, nebo např. v kapitole 29 oddílu 7 1Aktiebolagslag (2005:551) a požadovanou výši podílu pro vytěsnění v upravenou v kapitole 22, oddílu 1 Aktiebolagslag (2005:551).

17 Jak ve svém článku upozorňuje M. Burkart a F. Panunzi, tzv. Winterova zpráva (viz pozn. pod čarou č. 15) obhajuje zavedení práva sell-out poukázáním na skutečnost, jež však fakticky vyznívá negativně proti právu squeeze-out (obhajovaným však na mnoha jiných místech zprávy). V každém př́padě je tím podtržen závěr, že bez zavedení práva sell-out by zakotvení práva squeeze-out mohlo představovat reálnou hrozbu z hlediska ochrany práv menšinových akcionářù. Srov. BURKART, Mike, PANUNZI, Fausto. Mandatory Bids, Squeeze-out, Sell-out and the Dynamics of the Tender Offer Process. ECGI - Law Working Paper [online]. 2003, No. 10, s. 20 [cit. 10. 11. 2016].

18 Gesetzentwurf der Bundesregierung Entwurf eines Gesetzes zur Regelung von öffentlichen Angeboten zum Erwerb von Wertpapieren und von Unternehmensübernahmen [online]. 2001, Drucksache 14/7034, s. 31 [cit. 12. 11. 2016]. Dostupné z: http://dip21.bundestag.de/dip21/btd/14/070/1407034.pdf 
muluje. ${ }^{19}$ Přístupy jednotlivých zemích zakotvujících následný sell-out se dále liší v tom, zda je pro následný sell-out právně závazná nabídka původní, či zda vzniká povinnost předložit novou nabídku k odkupu zbývajících účastnických cenných papírů.

První prrístup je aplikován nap̌r. v německé právní úpravě následného práva sell-out (『 39c Wertpapiererwerbs- und Übernahmegesetz - WpÜG), umožňující menšinovým akcionářům, jež neakceptovali původní nabídku převzetí, dodatečné přijetí této nabídky ve lhůtě 3 měsíců od konce závaznosti původní nabídky převzetí, prokážou-li, že předkladatel nabídky převzetí splňuje podmínky pro následný squeeze-out podle $\int 39 \mathrm{a}$ Wü̈G. Z pohledu právní úpravy nabídek převzetí se zjednodušeně řečeno jedná v podstatě o situaci funkčně srovnatelnou s prodloužením doby závaznosti původní nabídky převzetí. ${ }^{20}$

Tuzemská právní úprava následného sell-out je založena na druhém př́stupu, který nespočívá v prodloužení původní nabídky, ale v povinnosti učinit nabídku novou. Dodatečná nabídka převzetî́i ${ }^{11}$ predstavuje povinný neomezený a nepodmíněný veřejný návrh smlouvy, který je povinen učinit předkladatel neomezené a nepodmíněné nabídky převzetí, pokud v jejím důsledku nabyl účastnické cenné papíry cílové společnosti představující alespoň $90 \%$ podíl na hlasovacích právech a na základním kapitálu cílové společnosti, a to do 30 dnů od posledního dne doby závaznosti nabídky převzetí, na základě které mu tato povinnost vznikla. ${ }^{22}$ Pokud jde o konkrétní proceduru odkupu, stanoví právní úprava přiměřené použití ustanovení o povinné nabídce převzetí.

Zvláštním důvodem pro zavedení práva sell-out do právní úpravy je možné psychologické působení na akcionáře oslovené v rámci nabídky převzetí. Konkrétně by mělo právo sell-out napomoci ke snížení tlaku vnímaného akcionáři oslovenými nabídkou převzetí, vyvolaného očekáváním pravděpodobných negativních dopadů spojených s odmítnutím

19 Př́́kladem právní úpravy spojující realizaci práva sell-out pouze s předchozí nabídkou převzetí je např. Německo. Ačkoliv německá právní úprava umožňuje jak následný, tak korporátní squeeze-out, obecné právo sell-out upraveno není. Možnost odkupu (Andienungsrecht) se nabízí pouze v kombinaci s předchozí nabídkou převzetí (〔 39c Wertpapiererwerbs- und Übernahmegesetz - WpÜG).

20 Následný sell out pojatý jako prodloužení původní nabídky převzetí, v jejímž důsledku získal předkladatel nabídky $90 \%$ podíl na základním kapitálu společnosti, upravovala v minulosti např. rakouská úprava, a to v \19 odst. 4 rakouského zákona o nabídkách převzetí - Bundesgesetz über den Ausschluss von Minderheitsgesellschaftern.

21 Rovněž dodatečná nabídka převzetí (vedle nabídky odkoupení dle \183h zákona č. 513/1991 Sb., obchodní zákoník, ve znění pozdějších předpisů - ObchZ) byla v minulosti prezentována jako právo sell-out. Ačkoliv lze souhlasit s tím, že úpravou dodatečné nabídkové povinnosti došlo k transponování práva sell-out dle čl. 16 Směrnice o nabídkách převzetí (viz Důvodová zpráva k zákonu č. 104/2008 Sb., o nabídkách převzetí a o změně některých dalších zákonů (zákon o nabídkách převzetî), č. 104/2008 Dz [online], s. 3 [cit. 11. 11. 2016].), nejednalo se o obecné právo odkupu, tj. právo uplatnitelné kdykoliv, a bez ohledu na veřejnou obchodovatelnost akcií emitovaných akciovou společností. Zakotvením práva dodatečné nabídkové povinnosti tak vznikla určitá nerovnost, kdy právo squeeze-out bylo aplikovatelné kdykoliv, ve všech akciových společností bez rozdílu, zatímco právo sell-out bylo časově omezeno a umožněno pouze v kotovaných společnostech.

22 \49 zákona č. 104/2008 Sb., o nabídkách převzetí a o změně některých dalších zákonů (zákon o nabídkách převzetî) ve znění pozdějších předpisů. 
nabídky, vedoucí k akceptaci hodnotu nevytvářejících nabídek převzetí v situaci, kdy je již jen minimální pravděpodobnost udržení likvidního trhu s cennými papíry cílové společnosti. ${ }^{23}$ Předmětem obav se může stát zejména uzamčení ve společnosti bez možnosti zpeněžení investice, jež se po nabídce převzetí stane obtížně likvidní (pressure to tenderproblem).${ }^{24}$ Zdrojem nejistoty menšinových akcionářu může být rovněž předpokládaný větší prostor pro zneužití postavení ze strany nové kontrolující osoby. ${ }^{25}$ Prostřednictvím sell-out je menšinovým akcionářům poskytnuta „druhá šance“ $\mathrm{k}$ využití původně odmítnuté nabídky. ${ }^{26}$ Nabídka převzetí tak nebude akceptována ze strachu, že akcionář zůstane jediným, kdo nabídku neakceptoval'“. ${ }^{27}$

K uskutečnění práva sell-out budou menšinoví vlastníci nakloněni zejména v tom případě, kdy hodnota společnosti po uskutečnění nabídky převzetí (post-take over value) bude nižší, než hodnota před realizací transformačního procesu (pre-take over value). ${ }^{28}$ Jelikož je menšinovým akcionářům $\mathrm{v}$ př́padě využití práva následného sell-out zaručeno poskytnutí prriměřeného protiplnění zásadně ve výši nabídkové ceny (bid price), je riziko jejich prodělku v důsledku neakceptace původní nabídky minimalizováno. Výhoda ve formě zvýšené ochrany menšinových akcionářủ původně nereflektující nabídku odkupu se pochopitelně projevuje negativně z pohledu výsledné efektivity nabídky převzetí, nebot' snižuje zisky předkladatele nabídky. ${ }^{29}$

Rovnováhu mezi požadavky efektivity na straně jedné, a ochrany zájmů drobných akcionářů na straně druhé, je proto nutné docílit pomocí práva squeeze-out, které rovnoměrnější distribuci zisků souvisejících s uskutečněním nabídky převzetí kompenzuje tím,

23 Srov. Důvodovou zprávu k zákonu č. 104/2008 Sb., o nabídkách převzetí a o změně některých dalších zákonů (zákon o nabídkách převzetî), č. 104/2008 Dz [online], s. 3 [cit. 11. 11. 2016]. Dostupné z: www. psp.cz/sqw/text/orig2.sqw?idd $=79488$

24 WINTER, Jaap et al. Report of the High Level Group of Company Law Experts on Issues Related to Takeover Bids [online]. Brusel: Evropská komise, 2002, s. 62 [cit. 10. 11. 2016].

25 Jak přitom uvádí ve svém článku Davies, ke znepokojení akciové minority souvisejícím se zvýšeným rizikem zneužití vlivu kontrolující osoby může dojít i při nabytí mnohem nižšího podílu, než který je požadován pro realizaci práva squeeze-out, umožňujícího pouze prostou kontrolu cílové společnosti. DAVIES, Paul. L. The Notion of Equality in European Take-over Regulation. Working Paper Series [online]. 2002, s. 10-11 [cit. 11. 11. 2016]. Dostupné z: https://papers.ssrn.com/sol3/papers.cfm?abstract_id=305979

26 Odmítnutí bývá v praxi zdůvodněno typicky nespokojeností s nabídkovou cenou. $\mathrm{V}$ př́padě úspěchu nabídky (tedy $\mathrm{v}$ př́padě její akceptace potřebným množstvím akcionářù, kteří nabídkovou cenu za nízkou nepovažovali), je akcionář, jež původní nabídku odmítl do určité míry zvýhodněn, nebot' v př́padě sell-out nemůže dostat nižší protiplnění, než jaké bylo nabídnuto při předchozí nabídce převzetí.

27 HAVEL, Bohumil, PIHERA, Vlastimil. Zákon o nabidkách prevz̨etí. 1. vyd. Praha: Nakladatelství C. H. Beck, 2009, s. 135. ISBN 978-80-7400-051-5.

28 VAN DER ELST, Christoph, VAN DEN STEEN, Lientje. Opportunities in the M \& A aftermarket: squeezing out and selling out. Universiteit Gent Financial Law Institute Working Paper [online]. 2006, No. 12, s. 3 [cit. 11. 11. 2016].

29 GOERGEN, Marc, MARTYNOVA, Marina, RENEBOOG, Luc. Corporate Convergence: Evidence from Takeover Regulation Reforms in Europe. ECGI - Law Working Paper [online]. 2005, s. 12-15 [cit. 11. 11. 2016]. Dostupné z: https://papers.ssrn.com/sol3/Papers.cfm?abstract_id=709023 
že brání spekulativnímu jednání drobných investorů vedoucímu k umělému navyšování nabídkové ceny (free-rider problem) a zvyšuje atraktivitu nabídek převzetí. ${ }^{30}$ Lze konstatovat, že již zmíněná komplementarita práva squeeze-out a sell-out se projevuje rovněž v kontextu nabídek převzetí.

\section{Právo odkupu (\$ $395 \mathrm{ZOK})$}

S účinností od 1. ledna 2014 bylo do českého právního řádu zakotveno obecné právo sell-out (〔 395 ZOK) umožňující menšinovým akcionářům zpeněžení jejich jinak nelikvidní investice v situaci, kdy jsou splněny podmínky pro vytěsnění (『375 ZOK). Právní úprava sell-out implementuje čl. 16 Směrnice o nabídkách převzetí, zároveň však úpravu obsaženou v evropské direktivě rozšiřuje z hlediska jejích aplikačních dopadů, nebot' právo sell-out není podmíněno předchozí nabídkou převzetí a není tedy ani časově omezeno. Právo odkupu je navíc přiznáno i menšinovým akcionářo̊m akciových společností, jejichž účastnické cenné papíry nebyly přijaty k obchodování na evropském regulovaném trhu.

Zakotvení obecného práva odkupu se neobešlo bez problémů. Zmínit je nutné v prvé radě dřívější diskuze $\mathrm{v}$ odborných kruzích polemizující s přítomností či nepřítomností práva odkupu v tuzemském právním řádu ${ }^{31}$, přičemž závěry autorů shledávajících absenci výslovné úpravy zkoumaného institutu vyznívaly převážně kriticky. ${ }^{32}$ Absence právní regulace sell-out přitom byla vytýkána mj. i Ústavním soudem, který dospěl v klíčovém nálezu zabývajícím se otázkou ústavní konformity právní úpravy vytěsnění k závěru, že „ke vyváženosti právni úpravy postaveni minoritnich akecionáru by príspèlo, kedyby zákonodárce upravil rovnéž jejich právo na to, aby v takové situaci blavni akcionár mél nejen právo, ale i povinnost na jejich žádost jejich akecie odkoupit (tzv. sell-out, popr. nabidková povinnost). "'B3

Přijetím právní úpravy práva odkupu účastnických cenných papírů menšinových akcionářů v souvislosti s rekodifikací soukromého práva tak byly definitivně ukončeny veškeré diskuze na téma výskytu práva sell-out v českém právním řádu. Objevily se však problémy nové, týkající se výkladu právní úpravy sell-out, vměstnané pouze do jednoho stručného ustanovení (\395 ZOK). Zhodnocení české právní úpravy práva sell-out včetně naznačení možných řešení výkladových nejasností je proto předmětem následujícího rozboru.

30 BURKART, Mike, PANUNZI, Fausto. Mandatory Bids, Squeeze-out, Sell-out and the Dynamics of the Tender Offer Process. ECGI - Law Working Paper [online]. 2003, No. 10, s. 7, s. 26 [cit. 10. 11. 2016].

31 V historii právní úpravy se vyskytly např́iklad názory spojující právo sell-out s institutem nabídky odkoupení dle $\int 183 \mathrm{~h}$ ObchZ (v platnosti do 31. 3. 2008). Tento institut (v praxi nevyužívaný) však nebylo možné považovat za sell-out, a to jednak vzhledem k požadavku existence zvláštní materiální podmínky, a dále ke skutečnosti, že realizace nabídky odkoupení byla závislá na rozhodnutí ČNB o uložení povinnosti učinit nabídku na odkoupení účastnických cenných papírů cílové společnosti. Srov. usnesení Ústavního soudu ze dne 31. března 2011, sp. zn. III. ÚS 1887/09.

32 Např. ZIMA, Petr. Freeze-out. Právní roz̧bledy, 2012, roč. 20, č. 20, s. 710-713.

33 Srov. bod 62 nálezu Pl. ÚS 56/05 ze dne 27. března 2008. 


\subsection{Podmínky realizace práva odkupu}

Právní úprava práva odkupu poskytuje vlastníkům účastnických cenných papírů, vůči kterým může hlavní akcionář uplatnit právo vytěsnění podle $\int 375 \mathrm{ZOK}$, možnost žádat, aby hlavní akcionář jejich účastnické cenné papíry odkoupil, a to postupem podle ustanovení o povinném veřejném návrhu smlouvy (\$327 ZOK).

Právo sell-out je považováno za komplementární s právem sell-out. Z tohoto důvodu se vyžaduje zrcadlení podmínek, jejichž splnění je nezbytné pro realizaci obou institutů. Předpoklady uplatnění práva odkupu jsou v podstatě pouze dva, a to existence osoby s postavením hlavního akcionáře ve smyslu \375 ZOK a dále podání žádosti o odkup účastnických cenných papírů. Mezi předpoklady uplatnění práva sell-out tak nepatří existence zvláštního materiálního důvodu, např. ve formě podstatného zhoršení postavení menšinového akcionáře či ohrožení jeho zájmů, ani schválení ze strany České národní banky. ${ }^{34}$ Právo odkupu rovněž není vázáno na existenci časové podmínky či výskyt předchozí nabídky provevetí. ${ }^{35}$

\subsubsection{Existence blavního akcionáre}

Pokud jde o podmínky uplatnění práva odkupu, je nutné vycházet primárně z podmínek pro realizaci práva squeeze-out (\375 ZOK), na které právní úprava práva odkupu př́mo odkazuje. Právo vystoupit na žádost ze společnosti je tak spojena se situací, kdy hlavní akcionář sice dosáhl prahové hodnoty pro vytěsnění, avšak svého práva nevyužil. V praxi bude k takovým př́padům docházet spíše ojediněle, např. v situaci, kdy na realizaci vytěsnění všech ostatních vlastníků účastnických cenných papírů nebude mít hlavní akcionář dostatek finančních prostředků potřebných pro uskutečnění výkupu (kromě částky potřebné na vyplacení přiměřeného protiplnění včetně úroků se jedná též o administrativní náklady transakce a odměnu pro znalce a osobu pověřenou výplatou protiplnění atd.).

Konkrétní výše maximální prahové hodnoty, kterou menšinový akcionář (resp. skupina menšinových akcionářů) nesmí překročit, je inverzní ve vztahu k výši rozhodného podílu pro squeeze-out. Je-li tedy rozhodný podíl pro realizaci vytěsnění stanoven ve výši nejméně $90 \%$ podílu na základním kapitálu, na něž byly vydány akcie spojené s hlasovacím právem a současně na hlasovacích právech (\375 ZOK), pak je právo na odkup spojeno s kumulativním splněním podmínek, zaprvé nepřekročení podílu ve výši $10 \%$ na základním kapitálu spojeného s hlasovacími právy, zadruhé s nepřekročením 10\% podílu na hlasovacích právech.

Dosažení, resp. nepřekročení rozhodného podílu pro sell-out v konkrétním prrípadě může být komplikováno skutečností, že o splnění podmínky může v praxi rozhodovat

\footnotetext{
34 Srov. \183h ObchZ.

35 Srov. \49 zákona o nabídkách převzetí.
} 
hlavní akcionář. K zabránění realizace práva na odkup mu totiž stačí účelový převod potřebného množství akcií, po jehož realizaci bude podmínka zmařena. ${ }^{36}$ Takto uměle „vyčleněný“ podíl pak může hlavní akcionář (resp. v tuto chvíli již ,jen“ majoritní akcionář) převést na spř́ízněnou osobu.

Domnívám se, že nejjednodušší formou řešení problému zmaření podmínek pro uskutečnění práva sell-out by mohlo být zavedení pravidla odečítání podílu spřízněných osob od menšinového podílu, jehož výše je rozhodná pro uplatnění obecného práva sell-out. $\mathrm{V}$ podstatě by se tak jednalo o obrácení pravidla přičítání podílů, jež je přítomné v řadě národních právních úprav vytěsnění. ${ }^{37}$

Zajímavou otázkou je možnost přičítání podílů i v kontextu stanovení dodatečné nabídkové povinnosti, tedy v rámci následného sell-out (\ 49 zákona o nabídkách převzetî). ${ }^{38}$ Dodatečnou nabídku převzetí lze totiž kategorizovat jako zvláštní druh povinné nabídky, pro kterou \37 zákona o nabídkách převzetí stanoví povinnost prričítání podílů. Ačkoliv komentářová literatura výslovně uvádí, že z obecné úpravy nabídkové povinnosti se uplatní pouze základní úprava procesu schvalování a úprava zániku nabídkové povinnosti se souhlasem $\check{C} \mathrm{NB}^{39}$, mám za to, že s ohledem na výše zmíněný smysl právní úpravy, kterým je zabránění uzamčení menšinových akcionářů ve společnosti, resp. eliminaci jejich spekulativního jednání vedoucího k negativním výsledkům (akceptace nekvalitní

36 Srov. LASÁK, Jan, POKORNÁ, Jarmila, ČÁP, Zdeněk, DOLEŽIL, Tomáš a kol. Zákon o obchodních korporacích. Komentár. Praha: Wolters Kluwer ČR, 2014, s. 1743. ISBN 978-80-7478-537-5. Obdobného efektu lze docílit samožrejmě i jinak, např. vhodně strukturovanou podnikovou kombinací či změnou právní formy.

37 Některé právní řády umožňují zohlednit při výpočtu potřebného podílu pro realizaci práva squeeze-out i podíly vlastněné jiným subjektem, pokud je mezi ním a hlavním akcionářem těsná spojitost, typicky vztah ovládání. Za velmi benevolentní lze označit nap̌r. německou úpravu opírající se o obecné pravidlo uvedené v S 16 odst. 4 Aktiengesetz (Zurechnung von Kapitalanteilen). Vysloveny byly dokonce i názory, že hlavní akcionář sám nemusí bezprostředně vlastnit žádné akcie společnosti, u které má dojít k vytěsnění, stačí, že potřebným podílem disponuje zprostredkovaně, přičemž relevantní je držení podílu na cílové společnosti jak na vertikální úrovni koncernové struktury, tak na úrovni horizontální. Viz např. usnesení Vrchního zemského soudu ve Stuttgartu (OLG Stuttgart) ze dne 18. 12. 2009, sp. zn. 20 W 2/08. O něco přísněji se k otázce přičítání podílů staví rakouská právní úprava stanovící časovou podmínku spojení členů koncernu trvající bez přerušení alespoň jeden rok před konáním valné hromady rozhodující o žádosti hlavního akcionáře ( $\int 1$ odst. 3 Bundesgesetz über den Ausschluss von Minderheitsgesellschaftern).

38 Základní podmínkou vzniku dodatečné nabídkové povinnosti je uskutečnění nabídky převzetí a dosažení zákonem stanovené prahové hodnoty v důsledku uskutečněné nabídky. Prahová hodnota pro vznik povinnosti předložení nabídky převzetí je formulována podobně, jako je stanoven kvalifikační práh vytěsnění podle $\int 395$ ZOK, avšak se dvěma rozdíly. Zaprvé, z povahy věci je zapotřebí, aby k nabytí podílu došlo v důsledku nabídky převzetí. Získání celého požadovaného podílu pouze prostřednictvím nabídky převzetí, tedy s vyloučením jiných zpơsobů nabytí podílu, však vyžadováno není. Zadruhé, dle $\int 49$ zákona o nabídkách převzetí se nepožaduje, aby byl 90\% podíl na základním kapitálu spojený pouze s akciemi s hlasovacím právem.

39 HAVEL, Bohumil, PIHERA, Vlastimil. Zákon o nabidkách prée z̧etí. 1. vyd. Praha: Nakladatelství C. H. Beck, 2009, s. 135. 
nabídky pod tlakem), by bylo vhodné pravidlo přičítání podílů aplikovat též v kontextu dodatečné nabídkové povinnosti.

\subsection{2 Žádost menšinového akcionáře o odkup účastnických cenných papiri}

Druhou podmínkou pro realizaci práva odkupu dle $\int 395$ ZOK je podání žádosti o odkup účastnických cenných papírů. Požádat hlavního akcionáře o odkup může kterýkoliv vlastník účastnických cenných papírů, přičemž svoji žádost nemusí (stejně jako hlavní akcionář v př́padě žádosti o squeeze-out) odůvodňovat (nap̌r. tvrzeními, že trh s akciemi, které vlastní, je skutečně nelikvidní, nebo že akcie nelze za prodat za férovou cenu apod.). Forma uplatnění práva není stanovena, stejně tak není předepsán časový okamžik podání žádosti. Promlčení práva na odkup z povahy věci nepřipadá v úvahu. ${ }^{40}$ Může tak být uplatněno kdykoliv, platí-li, že je ve společnosti hlavní akcionář.

\subsection{Způsob realizace práva odkupu}

Postup odkupu je upraven výslovným odkazem na právní úpravu povinného veřejného návrhu smlouvy (\327 a násl. ZOK). Povinný veřejný návrh smlouvy je veřejný návrh smlouvy učiněný navrhovatelem ke splnění zákonem uložené povinnosti odkoupit účastnické cenné papíry ( $\int 327$ ZOK). Zákonem uložená povinnost učinit veřejný návrh smlouvy se vztahuje nejen na uplatnění práva sell-out, ale i na další situace spojené se změnami ve vnitřních poměrech korporace, v jejichž důsledku klesá likvidita cenných papírů postižených touto změnou. Jedná se např́klad o přijetí rozhodnutí o vyřazení účastnických cenných papírů společnosti z obchodování na evropském regulovaném trhu ( 333 a násl. ZOK), rozhodnutí o změně druhu akcií nebo o omezení převoditelnosti akcií na jméno nebo zaknihovaných akcií anebo o jejím zprrísnění (\335 ZOK), či rozhodnutí o fúzi nebo rozdělení spojené s nerovnoměrným výměnným poměrem ( $\int 49 \mathrm{a}$ a násl., \145, \308 PřemZ). Smyslem institutu veřejného návrhu smlouvy je „umožnit majiteliom ǘrastnických cenných papiru omezit z̦tráty v dìsledku sniženi likvidity a možného poklesu bodnoty doť̌ených cenných papirui tím, že realizuji zánike účasti ve společnosti formou prodeje účastnických cenných papiru za cenu primérénou jejich hodnotě. "41

V kontextu zmíněného smyslu lze veřejný návrh v obecné rovině považovat za $\mathrm{v}$ principu použitelný nástroj pro realizaci práva sell-out. Aplikace právní úpravy veřejného návrhu na postup při odkupu účastnických cenných papírů menšinových akcionářù na jejich žádost nicméně vyvolává některé dílčí výkladové problémy spojené se specifiky práva sell-out.

40 LASÁK, Jan, POKORNÁ, Jarmila, ČÁP, Zdeněk, DOLEŽIL, Tomáš a kol. Zákon o obchodních korporacích. Komentár. Praha: Wolters Kluwer ČR, 2014, s. 1743.

41 Viz Znalecképosudky pro účly povinných nabidek prevęetí a verejných návrbu smluv o koupi účastnických cenných papirù (ZNAL) [online]. 2004, s. 3 [cit. 11. 11. 2016]. Dostupné z: https://www.cnb.cz/miranda2/export/.../ metodika_znal_20040826.pdf 
Z hlediska teorie i praxe lze za nejproblematičtější označit níže uvedené otázky, jejichž analýza bude předmětem dalších úvah:

- absence konkrétní lhůty pro splnění povinnosti učinění veřejného návrhu na odkup,

- náhradní řešení při porušení povinnosti,

- existence povinnosti přjetí návrhu.

\subsubsection{Lhưta pro učinèni veréjnébo návrhu na odkup účastnických cenných papiri}

Ačkoliv je právní úprava povinného veřejného návrhu poměrně podrobná, vyvolává její přímé použití v případě realizace práva sell-out řadu interpretačních nejasností. Mezi nejpalčivější problémy patří na prvním místě absence lhůty pro splnění povinnosti učinění veřejného návrhu na odkup účastnických cenných papírů.

Povinnost hlavního akcionáře učinit veřejný návrh smlouvy na koupi všech ostatních účastnických cenných papírů společnosti vzniká v okamžiku doručení žádosti ze strany oprávněné osoby. Povinnost hlavního akcionáře učinit povinný veřejný návrh smlouvy na odkup účastnických cenných papírů společnosti se přitom z logiky věci nevztahuje pouze na žadatele, ale na všechny ostatní vlastníky. Lhưta pro učinění návrhu (splnění povinnosti) není stanovena, takže chybí kritérium, podle kterého by bylo možné posoudit vznik prodlení spojený se vznikem práva předkladatele žádosti o odkup předložit návrh vlastní či aktivovat jiné náhradní řešení. ${ }^{42}$

V komentářové literatuře se lze setkat s velmi odlišnými názory na délku lhůty pro splnění povinnosti. Jedním z návrhů je aplikace maximálně 30denní lhůty od doručení žádosti oprávněného vlastníka stanovené pro veřejný návrh (\$331 odst. 1 ZOK, \335 odst. $1 \mathrm{ZOK}) .{ }^{43}$ Domnívám se, že tento požadavek je pro sell-out neaplikovatelný, jelikož se vztahuje na zvláštní situace (delisting, resp. změnu druhu či převoditelnosti akciî). $\mathrm{V}$ uvedených případech dochází ke změně poměrů z iniciativy majoritního akcionáře, který tak má ve svých rukou načasování transakce (včetně jeho přípravy a obstarání potřebných podkladů), což však pro sell-out iniciovaný menšinovým akcionářem neplatí.

Jiný názor prezentovaný právní naukou obhajuje lhůtu několikanásobně delší, a to cca tříměsíční, počítanou od doručení žádosti hlavnímu akcionáři. ${ }^{44}$ Domnívám se, že uvedený návrh více reflektuje praktické hledisko, např́klad časové náklady spojené s prrípravou veřejného návrhu obligatorně zahrnujícího mimo jiné i návrh protiplnění ve výši přimě-

42 Naopak pro následný sell-out ( $\$ 49$ zákona o nabídkách převzetî) je lhůta stanovena výslovně. Dodatečnou nabídku převzetí musí povinná osoba učinit do 30 dnů od posledního dne doby závaznosti nabídky převzetí, $\mathrm{v}$ jejímž důsledku mu vznikla povinnost dodatečnou nabídku převzetí učinit, a to všem vlastníkům účastnických cenných papírů cílové společnosti přijatých k obchodování na regulovaném trhu.

43 BĚLOHLÁVEK, Alexander, J. a kol. Komentár k zákonu o obchodních korporacích. Plzeň: Aleš Čeněk, 2013, s. 1656. ISBN 978-80-7380-451-0.

44 LASÁK, Jan, POKORNÁ, Jarmila, ČÁP, Zdeněk, DOLEŽIL, Tomáš a kol. Zákon o obchodních korporacich. Komentár. Praha: Wolters Kluwer ČR, 2014, s. 1743. 
řené hodnotě účastnických cenných papírů, doložený posudkem znalce ( $\int 328$ odst. 1 ZOK). V případě 30denní lhůty lze mít pochybnosti o reálné možnosti vyhotovení znaleckého posudku v tak krátkém čase. Delší lhůta pro splnění povinnosti učinit veřejný návrh rovněž více koresponduje s faktickou délkou procesu squeeze-out (jehož př́prava a realizace se počítá v řádech několika měsíců až cca půl roku).

Při posouzení délky lhůty pro učinění veřejného návrhu je nutné vzít v úvahu rovněž případnou lhůtu pro rozhodování České národní banky o povolení návrh uveřejnit (\$ 337 ZOK $)^{45}$. Domnívám se však, že v případě vlastníků účastnických cenných papírů přijatých $\mathrm{k}$ obchodování na evropském regulovaném trhu bude $\mathrm{z}$ povahy věci docházet ke vzniku potřeby odkupu podílů prostřednictvím institutu sell-out spíše zcela ojediněle.

\subsubsection{Nábradni rèéeni pri prodleni s prèdložením verejnébo návrhu}

Absence zákonné lhůty pro učinění veřejného návrhu na odkup se negativně projevuje i ve sféře pravidel upravujících náhradní řešení. Problém chybějící lhůty bránící exaktně určit prodlení hlavního akcionáře s plněním povinnosti učinit veřejný návrh však zdaleka není jediným problémem aplikace pravidel upravených v \329 ZOK. I kdybychom dospěli (čistě hypoteticky) k závěru, že lhůta k předložení návrhu bude stanovena v souladu $\mathrm{s}$ názorem prezentovaným $\mathrm{v}$ odborné literatuře $\mathrm{v}$ délce tří měsíců od předložení žádosti o odkup (nebude-li v konkrétním prrípadě dán důvod pro její prodloužení či zkrácenî), je zde množství dalších výkladových nejasností a praktických problémů.

$\mathrm{V}$ případě, že hlavní akcionář porušil povinnost učinit veřejný návrh smlouvy, vzniká oprávněnému vlastníkovi účastnických cenných papírů právo navrhnout uzavření smlouvy o koupi účastnických cenných papírů za prriměřené protiplnění. Hlavnímu akcionáři v takovém případě vzniká povinnost návrh přijmout ( $\int 329$ odst. 1 ZOK). Nebude-li návrh přijat do 15 pracovních dnů ode dne jeho doručení, může se oprávněný vlastník účastnických cenných papírů domáhat uzavření smlouvy u soudu v šesti měsíční prekluzivní lhůtě nebo požadovat náhradu újmy v téže lhůtě (\329 odst. 2 ZOK).

Výchozím problémem spojeným s formulací pravidel náhradního řešení při prodlení hlavního akcionáře s učiněním veřejného návrhu je nedostatečné koncepční uchopení práva sell-out. Je totiž otázkou, jak vlastně na právo sell-out nahlížet. Zatímco právo squeeze-out je právem výlučně individuální povahy, svědčící pouze a jedině hlavnímu akcionáři, právo sell-out může vykonat jakýkoliv vlastník účastnických cenných papírů (za předpokladu, že je ve společnosti hlavní akcionář), ale zároveň nejde o právo čistě individuální povahy $\mathrm{v}$ tom smyslu, že by z něj měl prospěch pouze žadatel, ale mohou z něj profitovat i další menšinoví vlastníci, byt’ oni sami o odkup nežádali.

$45 \int 337$ hovořící o stavění lhůty v důsledku předložení návrhu České národní bance se vztahuje pouze k situacím vymezeným zákonnou lhůtou (30 dní od doručení žádosti). Pro posouzení délky lhůty k učinění veřejného návrhu na odkup účastnických cenných papírů dle $\int 395$ ZOK bude zřejmě nutné aplikovat pravidlo stavění lhůty přiměřeně, tzn. prrihlédnutím k délce řízení před ČNB (〔331 a \332 ZOK). 
Právní nauka bohužel jednotné koncepční východisko odhalující podstatu práva sell-out nenabízí, což se velmi negativně projevuje ve chvílích, kdy je nutné vyřešit dílčí problémy spojené s jeho realizací. Tyto aplikační problémy přitom nelze překlenout ani cestou individuálního ujednání stran odchylujícího se od znění právní normy, vzhledem ke kogentní povaze právní úpravy sell-out. ${ }^{46}$

Lze se například setkat s přístupy pojímající mi právo sell-out více kolektivním způsobem, jako právo které sice může uplatnit i jen jeden vlastník účastnických cenných papírů, avšak s účinky pro vlastníky ostatní. Např. v komentáři k zákonu o obchodních korporacích je konkrétně vyjádřen názor, že zbývající vlastníci mohou uplatnit právo sell-out toliko jednou, s tím že ,Jakmile hlavni akcionár veřjný návrh smlouvy (k žádosti kteréhokoliv ze źbývajicich vlastnik.ů) učiní, je právo odkupu realizováno a nemuiže být uplatnèno žádným z ostatnich vlastniku napr. za dalšich puil roku opètovnè. Zbývajici vlastnici musi proto pečlivě quážit, zda vyuřiji práva na fair exit č zda ve společnosti s hlavním akcionárem (se všemi nevýhodami, které to prináši) nadále zuistanou." "47

Citované stanovisko tak de facto vychází ze vzájemné závislosti jednotlivých menšinových vlastníků účastnických cenných papírů. Tento pohled však dle mého názoru neodpovídá smyslu a účelu právní úpravy sell-out. Domnívám se rovněž, že pokud právní úprava neomezuje právo squeeze-out, kdy žádost o svolání valné hromady rozhodující o vytěsnění může hlavní akcionář teoreticky podávat i opakovaně, nelze omezit ani právo sell-out. Případné anomálie projevující se nadměrným podáváním žádostí, vždy po uplynutí závaznosti původně předložené nabídky, lze řešit prostřednictvím institutu náhrady škody, bude-li možné z okolností dovodit, že se v daném případě jedná např. o zneužití práva. Pravděpodobnější reakcí ze strany hlavního akcionáře zatíženého nadměrnými administrativními náklady by však dle mého názoru bylo spíše učinění vlastního návrhu na vytěsnění, či, v prrípadě nedostatku finančních prostředků, snížení rozhodného podílu pod hranici nutnou k realizaci práva squeeze-out, resp. sell-out. Problémem nahlížení na právo sell-out „kolektivním způsobem“ je dle mého názoru problematické i z toho důvodu, že je na menšinové akcionáře nahlíženo jako na skupinu osob s homogenními zájmy. Tak tomu však v praxi být nemusí. Teoreticky by mohla mezi hlavním akcionářem a některým z menšinových akcionářů existovat dohoda o tom, že menšinový vlastník akceptuje veřejný návrh na odkup jím vlastněných účastnických cenných papírů, byt' bude obsahovat pro něj nevýhodné podmínky, s cílem zabránit realizaci práva odkupu ostatním menšinovým akcionářům.

46 Důvodem kogentnosti je zde primárně účel právní normy (ochrana menšinových akcionárư). Podrobněji k této otázce viz ŠPAČKOVÁ, Michala. Smluvní možnosti limitace práva squeeze-out. Obchodněprávní revue, 2017, č. 1, s. 1-9.

47 ŠTENGLOVÁ, Ivana, HAVEL, Bohumil, CILEČEK, Filip, KUHN, Petr, ŠUK, Petr. Zákon o obchodnich korporacích. 1. vyd. Praha: Nakladatelství C. H. Beck, 2013, s. 600. 
Nevyjasněnost konceptu práva sell-out se projevuje v konkrétních situacích, jak lze doložit na několika př́kladech.

Zatímco v případě splnění povinnosti učinit veřejný návrh ze strany hlavního akcionáře má kterýkoliv z menšinových akcionářu možnost návrh akceptovat, $v$ př́padě náhradního řešení je uzavřena smlouva pouze mezi žadatelem o odkup a hlavním akcionářem (bez ohledu na to, zda byl neveřejný návrh akceptován hlavním akcionářem dobrovolně, nebo prostřednictvím nahrazení jeho projevu vưle soudem dle \329 odst. 2 ZOK). Hlavnímu akcionáři nacházejícímu se v prodlení se splněním návrhové povinnosti mohou být přitom předloženy různé návrhy jednotlivých menšinových akcionářuo obsahující rozdílné podmínky odkupu (např. odlišné podmínky pro odstoupení od smlouvy, různě vysoké smluvní pokuty či smluvní úroky atd.). Ustanovení \ 329 odst. 3 ZOK sice hovoří o možnosti žádat dorovnání, vyjde-li najevo, že vlastníci účastnických cenných papírů, které byly předmětem veřejného návrhu smlouvy, neobdrželi nebo nemají podle smlouvy obdržet přměřené protiplnění, uvedené řešení lze však označit za pouze částečné. V řízení o dorovnání jsou totiž řešeny pouze otázky týkající se přiměřenosti protiplnění, nikoliv další otázky vztahující se k obsahu smlouvy. ${ }^{48}$ Domnívám se, že soudní rozhodnutí o nahrazení projevu vưle nebo o přiznání náhrady újmy ( 329 odst. 2 ZOK), resp. rozhodnutí soudu přiznávající jinou výši protiplnění (\329 odst. 3 ZOK), musí být z povahy věci a z odkazu na právní úpravu řizení o dorovnání (\$ 390 ZOK) závazné, co do základu, i pro ostatní vlastníky účastnických cenných papírů. Právní jistotě by však velmi prospělo výslovné zakotvení takto rozšířených účinků individuálního soudního rozhodnutí. ${ }^{49}$

Další z analyzovaných výkladových problémů se týká stanovení přiměřeného protiplnění. Vyjdeme-li z doslovného jazykového vyjádření, má hlavní akcionář povinnost návrh přijmout tehdy, je-li protiplnění přiměřené. Je však otázkou, jaký vliv má nepřiměřené protiplnění na právo menšinového vlastníka požádat soud o uzavření smlouvy náhradním způsobem. Domnívám se, že nelze menšinovému akcionáři upírat možnost požadovat uzavření smlouvy prostřednictvím soudu, nedoložil-li výši protiplnění posudkem znalce (takovou povinnost má ostatně pouze hlavní akcionář, jak vyplývá z \ 328 odst. 1 ZOK),

48 Uvedený prrístup by de facto znamenal pomyslné rozdělení obsahu smlouvy o odkupu účastnických cenných papírů na část závaznou i pro ostatní menšinové vlastníky, a část individuální, která by byla závazná pouze inter partes. $\mathrm{V}$ podstatě by se tak jednalo o kombinaci požadavků rovného zacházení a zásady autonomie smluvní svobody. Uvedená kombinace je uvedena i v \390 odst. 6 ZOK, dle kterého platí, že dohodne-li se hlavní akcionár na dorovnání s vlastníkem účastnického cenného papíru mimo soudní řízení, je tato dohoda pro hlavního akcionáře závazná co do základu uznaného práva i vưči ostatním vlastníkům účastnických cenných papírů.

49 Domnívám se, že kromě výslovného zakotvení rozšiřujících účinků rozhodnutí soudu o uzavření smlouvy (nahrazení projevu vůle), co do základu práva na přiměřené protiplnění, by mohla být efektivním nástrojem proti prodlení s předložením veřejného návrhu též sistace hlasovacích práv hlavního akcionáře. Inspiraci lze nalézt konkrétně v \53 zákona o nabídkách převzetí zakotvujícím jako následek prodlení s plněním nabídkové povinnosti pozastavení hlasovacích práv osoby, které vznikla nabídková povinnost. 
či pokud později v průběhu řízení vyjde najevo, že jím navržené protiplnění není přiměřené. Bez podrobných informací o stavu hospodaření společnosti a př́istupu k účetním dokladům budou však možnosti menšinového akcionáře navrhnout protiplnění tak, aby splňovalo požadavky přiměřenosti, zpravidla velmi omezené. Pojem přiměřenosti navíc zahrnuje i otázku časovou. V kontextu práva squeeze-out se vychází z rozhodného okamžiku pro určení přiměřenosti protiplnění, kterým je den přechodu vlastnického práva na hlavního akcionáře ( 390 odst. 1 ZOK). Pokud by mělo být analogicky ${ }^{50}$ aplikováno totéž pravidlo i na sell-out, musela by být přiměřenost protiplnění stanovena k okamžiku, kdy má být realizován převod účastnických cenných papírů vlastněných předkladatelem návrhu. Tento okamžik však menšinový akcionář nezná, nebot’ nemůže předjímat, zda hlavní akcionáŕ jeho návrh akceptuje, či zda bude smlouva uzavřena náhradním způsobem a k jakému okamžiku.

Problematické je rovněž zakotvení šesti měsíční prekluzivní lhůty k uplatnění práva domáhat se u soudu uzavření smlouvy nebo náhrady újmy (\329 odst. 2 ZOK). Vyjdeme-li z předpokladu, že promlčení práva sell-out není s ohledem na ratio právní úpravy tohoto institutu přípustné, je otázkou, jaký smysl má stanovení uvedené prekluzivní lhůty, jejíž marné uplynutí lze teoreticky zmařit případným převodem akcií na jiného akcionáře, který může znovu požádat hlavního akcionáře o odkup. Pochybné je zakotvení prekluzivní lhůty i z toho důvodu, že pokud není lhůtou omezeno právo squeeze-out, pak dle mého názoru není možné připustit časové omezení práva sell-out, byt' se v zákoně uvedené omezení vztahuje $\mathrm{k}$ náhradnímu řešení aplikovatelnému v situaci, kdy dojde k prodlení hlavního akcionáře s povinností učinit vlastní veřejný návrh, resp. s povinností akceptovat návrh předložený menšinovým vlastníkem.

Další nelogičnost v pojetí pravidel zakotvujících náhradní řešení se týká stanovení práva dovolávat se dorovnání nepřiměřeného protiplnění (\$ 329 odst. 3 ZOK). Předně je nutné zpochybnit význam práva na dorovnání v situaci, kdy na rozdíl od práva squeeze-out nedochází $\mathrm{k}$ nedobrovolnému přechodu, ale $\mathrm{k}$ převodu, který lze $\mathrm{v}$ př́padě nesouhlasu s výší navrženého protiplnění jednoduše zmařit neakceptací návrhu. I pokud bychom však dospěli k závěru, že právo na dorovnání má svůj význam i v situacích, kdy k převodu dochází na základě svobodné vưle převodce ${ }^{51}$, brání smysluplné aplikaci uvedeného pravidla řada dalších nejasností. Zatímco v případě uplatnění práva domáhat se uzavření smlouvy je prekluzivní lhůta nesmyslná, domnívám se, že v případě uplatnění práva na dorovnání uvedení této lhůty chybí. (Dosavadnî) vlastníci účastnických cenných pa-

50 Právní úprava veřejného návrhu sice v \329 odst. 2 a 3 ZOK odkazuje na \390 ZOK, nikoliv však na jeho první dva odstavce.

51 Možnost žádat dorovnání právní řád spojuje i s jinými situacemi, kdy dochází k uzavření smlouvy mezi akcionáři. Jako příklad lze uvést akceptaci nabídky převzetí. Nezákonné stanovení výše protiplnění při nabídce převzetí tak nezpůsobuje neplatnost smlouvy vzniklé přijetím této nabídky, její př́jemce je však oprávněn domáhat se u soudu doplacení rozdílu mezi protiplněním uvedeným v nabídce převzetí a protiplněním ( 52 zákona o nabídkách převzetî). 
pírů tak mají právo dovolávat se toho, aby jim navrhovatel protiplnění dorovnal, vyjde-li najevo, že neobdrželi nebo nemají podle smlouvy ${ }^{52}$ obdržet přiměřené protiplnění, přičemž není specifikováno, jaké okolnosti jsou relevantní pro posouzení skutečnosti, že nepřiměřenost protiplnění vyšla najevo. Dále je nutné vytknout absenci možnosti uplatnit právo na dorovnání prrímo u hlavního akcionáře upravené v \390 odst. 1 a 2 ZOK, na které není odkazováno (〔 329 odkazuje pouze na odstavce 3 až 5 a odst. 7 \390 ZOK). Není zjevné, proč by se dosavadní vlastník nemohl obrátit nejprve na nabyvatele jeho akcií a až následně na soud.

\subsubsection{Povinnost prijmout návrh}

Povinnost přijmout návrh je třetí výkladově nejednoznačnou otázkou práva odkupu. Koncepční nevyjasněnost práva sell-out se neprojevuje negativně pouze v případě nesplnění nabídkové povinnosti, ale též v př́padě, že tato povinnost hlavním akcionářem splněna je. Konkrétně se jedná o otázku, zda je žadatel, který k učinění hlavního akcionáře vyzval, povinen hlavním akcionářem předložený veřejný návrh přijmout, či zda se taková povinnost vztahuje i na ostatní oprávněné vlastníky, zda takovou povinnost nelze dovodit vůbec, a to ani vưči původnímu žadateli, ani vůči oprávněným vlastníkům.

Domnívám se, že ze tří uvedených možností lze nejpřesvědčivěji vyloučit variantu zvažující rozšíření povinnosti přijmout návrh na všechny (tzn. i nežádajícî) oprávněné vlastníky. Právo sell-out je dle mého názoru s ohledem na jeho význam (mj. i jako opozita práva squeeze-out) nutné vnímat jako právo, nikoliv povinnost menšinových akcionárư. Připuštěním široce pojaté povinnosti všech oprávněných vlastníků přijmout předložený návrh by se fakticky z práva sell-out stalo právo squeeze-out, s tím rozdílem, že k nedobrovolnému odnětí vlastnického práva by došlo primárně $\mathrm{v}$ důsledku projevu vưle žadatele, nikoliv hlavního akcionáře. Jelikož se v daném prrípadě jedná o závěr ve svých důsledcích de facto relativizující význam sell-out jako nástroje ochrany minorit, považuji za nezbytné jej odmítnout.

Správná dle mého názoru není ani úvaha spojující povinnost akceptovat návrh pouze se žadatelem o odkup. Splnění povinnosti učinit veřejný návrh je sice obecně spojena s určitými administrativními náklady, kdy zejména odměna znalce provádějícího ocenění není zcela nezanedbatelným výdajem, nicméně zvýšené administrativní náklady na správu společnosti, ve které jsou př́tomní i menšinoví akcionáři je faktem, se kterým musí hlavní akcionář počítat. Případné zneužívání institutu práva na odkup lze navíc řešit prostřednictvím adekvátních institutů. Úvaha spojující právo žadatele o odkup s povinností akceptace návrhu dále neřeší situaci, kdy veřejný návrh sice bude učiněn, avšak navrže-

52 Domnívám se, že by správně měla být zahrnuta pod $\int 239$ odst. 3 ZOK i situace, kdy formálně vzato hlavní akcionář veřejný návrh sice učiní, tedy nedostane se do prodlení, ale jím navržené protiplnění nebude v rozporu s \328 odst. 1 ZOK přiměřené, tedy vyjde-li najevo, že podle návrhu smlouvy (tzn. dosud neakceptovaného) nemá dosavadní vlastník přiměřené protiplnění obdržet. 
né protiplnění nebude přiměřené. I kdybychom však dovodili, že se uvedený problém dá překlenout dorovnáním nepřiměřeného protiplnění v soudním řízení, není dále jasné ani to, jak by měla být povinnost akceptace vynucována, zda s využitím institutu nahrazení projevu vůle (který však právní úprava výslovně spojuje pouze s povinností učinit návrh, nikoliv s povinností návrh akceptovat), či zda by měl být konstruován dokonce přechod vlastnického práva $\mathrm{k}$ účastnickým cenným papírům žadatele, a pak k jakému datu (např. ke dni uplynutí závaznosti nabídky). Domnívám se proto, že i na žadatele je nutné hledět jako na osobu oprávněnou, nikoliv povinnou. ${ }^{53}$

\section{Právo na odkup ( $\$ 89$ a násl. ZOK)}

Vedle obecného práva sell-out (práva odkupu) a následného práva sell-out (dodatečné nabídkové povinnosti), poskytuje tuzemská právní úprava i zvláštní pravidla na ochranu menšinových společníků umožňující vystoupení ze společnosti, i proti vůli dominantního společníka. Za př́klad tuzemské verze zvláštního druhu práva sell-out lze považovat právo na odkup (\89 až \91 ZOK), jako specifický institut z oblasti koncernového práva.

Právo na odkup představuje zvláštní individuální právo společníků ovládané osoby (nejen akciové společnosti) požadovat, aby od něj ovládající osoba jeho podíl odkoupila za přiměřenou cenu a umožnila mu tak odchod ze společnosti. ${ }^{54} \mathrm{Ne}$ vždy je totiž pro mimostojící společníky reálně dosažitelné domáhat se odškodnění prostřednictvím reparační povinnosti ovládající osoby.

Realizace práva na odkup je vázána na splnění materiální podmínky spočívající v podstatném zhoršení právního postavení společníků nebo v jiném podstatném poškození jejich oprávněných zájmů. Nemožnost požadovat setrvání společníka ve společnosti je tak de facto měřítkem pro posouzení, zda je zhoršení jeho postavení podstatné. Použité kritérium je přitom do značné míry subjektivní a jeho naplnění v konkrétním případě bude nutné posoudit s prihlédnutím $\mathrm{k}$ individuálním skutkovým okolnostem. Dle odborné literatury lze mezi konkrétní př́klady podstatného zhoršení postavení zařadit např́klad opakovanou ztrátu práva na zisk či opakované faktické potlačení hlasovacích práv. Podstatné poškození jiných oprávněných zájmů lze spojit např́klad s nepřímým poškozením tržní ceny podílu prostřednictvím masivního poškození hodnoty majetku společnosti. ${ }^{55}$ V každém případě nicméně platí povinnost osoby domáhající se práva na odkup prokázat namítané zhoršení postavení, konkrétně skutečnosti, že kvalifikované újma vznikla

53 Shodně LASÁK, Jan, POKORNÁ, Jarmila, ČÁP, Zdeněk, DOLEŽIL, Tomáš a kol. Zákon o obchodních korporacích. Komentár. Praha: Wolters Kluwer ČR, 2014, s. 1742.

54 Vzhledem $\mathrm{k}$ následkům realizace práva se $\mathrm{v}$ právní nauce hovoř́ rovněž o právu exitu.

55 ŠTENGLOVÁ, Ivana, HAVEL, Bohumil, CILEČEK, Filip, KUHN, Petr, ŠUK, Petr. Zákon o obchodnich korporacích. 1. vyd. Praha: Nakladatelství C. H. Beck, 2013, s. 206. 
v důsledku reálného výkonu vlivu ovládající (řídícî) osoby v ovládané (rúizené) osobě. Pouhé tvrzení kvalifikovaného zhoršení poměrů ve společnosti tak k uplatnění práva nepostačí. Určitou zvláštností při prokazování existence materiální újmy je dělení důkazního břemene. Zatímco důkazní břemeno o tom, že došlo k podstatnému zhoršení postavení společníků nebo k jinému podstatnému poškození jejich oprávněných zájmů nese zásadně společník uplatňující právo na odkup, skutečnost, že ke zhoršení došlo v důsledku využití vlivu ovládající osoby v ovládané osobě, se presumuje (『90 ZOK) ${ }^{56}$. Pokud jde o způsob realizace práva na odkup, je společník ovládající osoby oprávněn požadovat, aby od něj ovládající osoba jeho podíl odkoupila na základě akceptace veřjejého návrhu předloženého ovládající osobou. Zajímavostí ve srovnání s obecným právem sell-out je „pouze“ obdobné použití ustanovení \ 328 a 329 ZOK o veřejném návrhu smlouvy, nikoliv zakotvení přímého odkazu na celou úpravu povinného veřejného návrhu. Přesto byl uvedený požadavek v literatuře vystaven kritice. ${ }^{57}$ Obecná úprava veřejného návrhu se tak ukazuje jako problematické místo právní úpravy, dostatečně nezohledňující specifika některých práv, jejichž realizace je ze zákona spojena právě s povinností veřejný návrh učinit.

Za odprodaný podíl náleží společníkovi přiměřená cena, jejíž výše se určí podle zvláštní právní úpravy obsažené v \91 ZOK. Způsob stanovení přiměřené ceny v zásadě odpovídá standardnímu zpo̊sobu ocenění používanému pro odhad hodnoty menšinových podílů při nedobrovolných transakcích. Ve srovnání s úpravou obecného práva sell-out je nicméně nutné vyzdvihnout konkretizaci pravidel pro stanovení protiplnění.

Předně, \ 91 ZOK zavádí do právní úpravy legislativní zkratku „hodnota závodu“, kterou je dle výslovné jazykové formulace hodnota majetku obchodní korporace s přihlédnutím $\mathrm{k}$ budoucímu provozu závodu, stanovená na základě posudku znalce jmenovaného na návrh ovládané osoby soudem. ${ }^{58}$ Domnívám se, že i přes ne zcela výkladově jednoznačnou formulaci stanovení ceny podílu v \91 odst. 1 ZOK, lze uvedený termín vyložit tak, že východiskem pro ocenění bude stanovení čistého obchodního jmění (nikoliv majetku) společnosti, beroucí v úvahu předpokládaný budoucí vývoj provozu závodu

56 Přes obtížněji srozumitelné jazykové vyjádření pravidla o dělení důkazního břemene lze vyložit znění druhého odstavce $\int 90$ ZOK, tak, že ovládající osoba nese důkazní břemeno ohledně toho, že ke vzniku kvalifikované újmy došlo bez jejího vlivu.

57 Srov. LASÁK, Jan, POKORNÁ, Jarmila, ČÁP, Zdeněk, DOLEŽIL, Tomáš a kol. Zákon o obchodních korporacích. Komentár. Praha: Wolters Kluwer ČR, 2014, s. 663; ŠTENGLOVÁ, Ivana, HAVEL, Bohumil, CILEČEK, Filip, KUHN, Petr, ŠUK, Petr. Zákon o obchodnich korporacích. 1. vyd. Praha: Nakladatelství C. H. Beck, 2013, s. 206-207.

58 Z logiky věci je pak osoba navrhovatele osobou nesoucí náklady na znalecký posudek. Ačkoliv $\int 91$ ZOK odkazuje v otázce jmenování znalce výslovně pouze na $\int 86$ ZOK pojednávajícím o jmenování znalce pro přezkum zprávy o vztazích, domnívám se, že aplikovatelný by měl být rovněž $\int 87$ ZOK dle kterého hradí odměnu znalci ovládaná osoba. 
(či závodů) a podnikání a tedy vycházející z úvahy o tzv. běžícím závodu (going concern). ${ }^{59}$ Konkrétně převáděný podíl se následně ocení některou ze standardních oceňovacích metod $^{60}$ dle pro rata principu, bez jakýchkoliv diskontů srážejících výslednou hodnotu.

Zadruhé, vzhledem ke kontextu uplatnění práva exitu je uvedené standardní pravidlo doplněno o zvláštní časové hledisko, dle kterého platí, že „Znalec urč hodnotu qávodu ovládané osoby, keterou mélv době, než došlo ke z̧horšeni postaveni společnikư nebo jinému podstatnému poškozeníjejich oprávnèných zájmü." (\$ $91 \mathrm{ZOK}$ ). Rozhodným okamžikem pro ocenění je tedy hodnota před zhoršením postavení, resp. poškozením zájmů.

Třetí zajímavostí je zvláštní pravidlo ohledně jmenování znalce pověřeného zpracováním posudku pro ocenění převáděného podílu soudem, a to na návrh ovládané osoby, tedy obdobně jako je tomu v situaci uvedené v \86 ZOK stanovícím pravidla jmenování znalce pro přezkum zprávy o vztazích a vyhotovení znaleckého posudku. Odměnu znalce a náklady za zpracování znaleckého posudku nese ovládaná, nikoliv ovládající, osoba. Zvláštní pravidla platí rovněž pro doručování znaleckého posudku, nebot’ posudek se doručuje jen navrhovateli a ovládající osobě. Společníkům, u nichž došlo ke zhoršení jejich postavení nebo jinému podstatnému poškození se posudek doručuje pouze tehdy, nemá-li společnost zř́zeny internetové stránky, kde je jinak povinna znalecký posudek uveřejnit s upozorněním pro společníky, kde je k nahlédnutí (\91 ZOK).

\section{Vztah práva odkupu a práva na odkup}

Na právo odkupu (\395 ZOK) a právo na odkup (\89 a násl. ZOK) lze nahlížet jako na instituty $\mathrm{v}$ zásadě ekvivalentní. ${ }^{61} \mathrm{~K}$ uvedenému závěru přispívá mimo jiné i fakt, že oba instituty představují ultimativní právo menšinových společníků aplikovatelné v situaci, kdy již není rozumné účast ve společnosti dále udržovat. Závěry vedoucí k tomu, že by se zkoumané instituty měly vzájemně vylučovat, či že by měl být použit jeden či druhý přednostně, proto považuji za rozporné se smyslem a účelem právní úpravy.

Hlavní výhodou práva na odkup (ve srovnání s právem odkupu) je absence požadavku téměř absolutně koncentrované vlastnické struktury ve společnosti. Práva na odkup se tak může dovolávat i společník vlastnící např. 25\% podíl na základním kapitálu. Vý-

59 ŠTENGLOVÁ, Ivana, HAVEL, Bohumil, CILEČEK, Filip, KUHN, Petr, ŠUK, Petr. Zákon o obchodnich korporacích. 1. vyd. Praha: Nakladatelství C. H. Beck, 2013, s. 209.

$60 \mathrm{~V}$ praxi velmi často používanou je metoda DCF (discounted cash-flow) vycházející z predikce hospodaření společnosti, konkrétně odhadu schopnosti zhodnocovat svůj majetek běžnou podnikatelskou činností. Metodu DCF lze použít, je-li splněna premisa going concern (předpoklad kontinuálního pokračování podnikání společnosti), a je-li hodnota závodu cílové společnosti tvořena především hodnotou peněžních toků, které závod v důsledků své činnosti realizuje. Z uvedeného důvodu je nevhodné použití metody DCF pro ocenění holdingových společností. U závodu holdingového typu lze však metodu DCF užít pro ocenění jednotlivých složek majetku a závazků.

61 LASÁK, Jan, POKORNÁ, Jarmila, ČÁP, Zdeněk, DOLEŽIL, Tomáš a kol. Zákon o obchodnich korporacích. Komentár. Praha: Wolters Kluwer ČR, 2014, s. 662. 
hodnost této skutečnosti se může projevit i v kontextu zmíněného rizika zneužití práva hlavním akcionářem spočivající v umělém zvětšování skupiny menšinových akcionářů. Uvedený pokus účelového zmaření podmínek pro sell-out by totiž mohl být kvalifikován jako využití vlivu v ovládané osobě vedoucí k podstatnému poškození oprávněných zájmů společníka, zde konkrétně zájmu spočívajícího v realizaci práva sell-out.

Další výhodou práva na odkup může být stanovení přesnějších pravidel pro stanovení přiměřené ceny. S ohledem na sledované ochranné důvody považuji pravidlo fixace ceny podílů k okamžiku před zhoršením postavení či poškozením zájmů za inspirativní i pro právní úpravu obecného sell-out, které $\mathrm{v}$ určitých situacích rovněž může fungovat jako ultima ratio. Domnívám se, že v případě splnění podmínek realizace obou práv, tedy jak obecného práva sell-out, tak práva na odkup může být $\mathrm{v}$ některých př́padech pro menšinového akcionáře výhodnější použít postup podle $\int 89$ ZOK, a to právě vzhledem k časovému okamžiku, od nějž se cena podílu stanoví. Problémem při snaze o analogickou aplikaci je nicméně skutečnost, zatímco v př́ípadě obecného sell-out se žádné důkazy svědčící o naléhavosti řešení situace vystoupením ze společnosti neprovádí, rozhodný okamžik pro stanovení ceny podílu při právu na odkup se vztahuje k důkazu, ze kterého vyplývá tvrzené zhoršení či poškození. Soud může nicméně důkazní břemeno obrátit, dospěje-li k závěru, že nesení důkazního břemene nelze po žádajícím společníkovi spravedlivě požadovat ( $\int 90$ odst. 1 ZOK). Tak tomu bude např. v situaci, kdy se tvrzení bude opírat o důkaz, který má ve své dispozici ovládající osoba.

Ačkoliv je právo na odkup primárně institutem koncernového práva, a je tedy zvláštním právem společníků ovládané osoby, domnívám se, že v praxi tato podmínka jeho př́padné využití jako určité alternativy obecného práva sell-out, resp. jeho funkční obdoby ${ }^{62}$, nesnižuje. Hlavní akcionář totiž bude v praxi v řadě př́padů zároveň ovládající osobou.

\section{Závěr}

Zakotvení obecného práva sell-out do právní úpravy lze s ohledem k jeho významu v oblasti ochrany práv menšinových společníků hodnotit pozitivně. Kladem tuzemské úpravy je zejména rozšíření požadavku Směrnice o nabídkách převzetí a umožnění práva odkupu i společníkům společností s nekótovanými akciemi. Z hlediska praktického využití jsou to totiž právě spíše společníci menších společností, kteří se v praxi potýkají s problémem uzamčení ve společnosti či útiskem ze strany dominantních akcionáruo zatímco akcionáři společností s veřejně obchodovatelnými akciemi mohou svoji investici zpeněžit z povahy věci snáze.

Aby však právo sell-out mohlo skutečně plnit svoji funkci a naplnilo tak poslání přisuzované mu právní naukou, musí existovat pravidla umožňující jeho skutečné využití v pra-

62 ŠTENGLOVÁ, Ivana; HAVEL, Bohumil; CILEČEK, Filip; KUHN, Petr; ŠUK, Petr. Zákon o obchodnich korporacích. 1. vyd. Praha: Nakladatelství C. H. Beck, 2013, s. 206. 
xi. V opačném př́padě, totiž půjde o právo sice formálně zakotvené v právním předpise, ale nenapomáhající ve skutečnosti k vyvažování postavení menšinových a dominantních akcionářů. Bude-li realizace práva sell-out spojena s nepřiměřenými obtížemi vzhledem $\mathrm{k}$ nejasně formulovaným či obtížně aplikovatelným dílčím pravidlům, může jeho zakotvení ovlivnit chování hlavního akcionáře, nebot' nedostatky právní úpravy obecného práva sell-out mohou potenciálně ohrozit i jeho zájmy.

Efektivnímu využití obecného práva sell-out brání zejména pravidla dostatečně nereflektující situaci menšinového akcionáře, pro kterého může být problematické jak učinění vlastního návrhu na odkup, tak domáhání se práva na uzavření smlouvy či práva na dorovnání protiplnění u soudu. Z věcných problémů lze dále jmenovat např́klad otázku zjištění, že jsou dány podmínky pro sell-out, možnost zmaření těchto podmínek z vůle hlavního akcionáře či problémy při navrhování přiměřeného protiplnění menšinovým akcionářem nedisponujícím potřebnými informacemi o hospodaření společnosti.

Za nejpalčivější výkladové problémy lze konkrétně označit absenci lhůty pro učinění návrhu na odkup, sporný význam prekluzivní lhůty k uplatnění práva domáhat se u soudu uzavření smlouvy nebo náhrady újmy, nejasné účinky dohody o odkupu, resp. soudního rozhodnutí o uzavření smlouvy o odkupu vůči ostatním akcionářům, či spory ohledně povinnosti návrh akceptovat.

Domnívám se, že východiskem pro řešení výše nastíněných problémů by mělo být $\mathrm{v}$ prvé řadě koncepční vyjasnění povahy práva sell-out, tak, aby nevznikaly pochybnosti o tom, zda sell-out představuje právo, které může aplikovat každý jednotlivý menšinový akcionář nezávisle na ostatních, či zda je na něj potřeba nahlížet jako na právo, jehož uplatnění má ve vztahu k ostatním menšinovým akcionářưm určité účinky, které je nutné brát při jeho realizaci v potaz.

Do doby přijetí koncepčně vyjasněného legislativního řešení či alespoň soudního rozhodnutí nabízejícího odpověd' na nastíněné otázky lze pro praxi doporučit využití smluvních nástrojů (akcionářských dohod obsahujících klauzuli o odkupu), v krajních případech pak využití zvláštního práva sell-out, tedy práva na odkup (\89 ZOK). Hlavní výhodou práva na odkup ve srovnání s obecným právem sell-out je zdůraznění individuální povahy práva umožňující jeho nezávislé použití, absence podmínky dosažení (nepřekročenî) rozhodného podílu a přesnější stanovení podmínek pro určení přiměřeného protiplnění. Obtíže spojené s nutností prokazovat kvalifikovanou újmu lze alespoň v některých př́padech překlenout rozhodnutím soudu o tom, že nesení důkazního břemene nelze po společníkovi žádajícím odkup spravedlivě požadovat. 